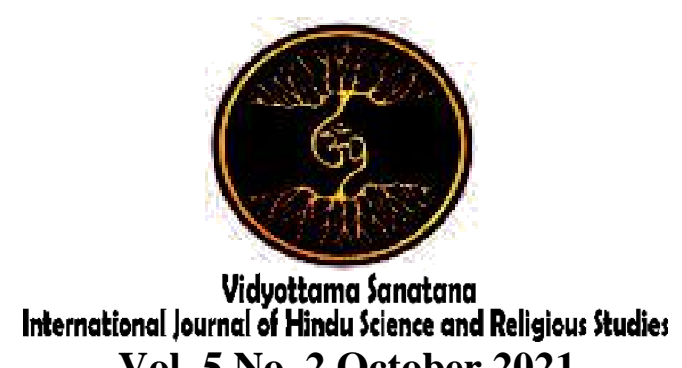

Vol. 5 No. 2 October 2021

\title{
SATWIKA LIFE STYLE \\ THROUGH THE DESIGN OF MEASURING EQUIPMENT BODY MASS INDEX (BMI) BASED ON IOT
}

\author{
By: \\ Kadek Ayu Ariningsih', Anak Agung Gede Ekayana², I Gede Andika ${ }^{3}$, I Kadek Rudi \\ Ariastawan ${ }^{4}$ \\ 1,2,3,4 STMIK STIKOM Indonesia
}

E-mail: 1ayuari@stiki-indonesia.ac.id, ${ }^{2}$ gungekayana@stiki-indonesia.ac.id, ${ }^{3}$ gdandika@stikiindonesia.ac.id, ${ }^{4}$ kdekrudi@gmail.com

Received: August 2, 2021

Accepted: August 5, 2021

Published: October 31, 2021

\begin{abstract}
The satwika lifestyle refers to the understanding that the physical body should be maintained through wise thoughts and behavior in determining what is good and bad for the body so that it is always in a fit and fit state. Technology affects the lifestyle of modern society. Practical lifestyles are not necessarily balanced with health awareness. Fast food variations and online food delivery services are practical choices even though they do not meet nutritional standards that can affect health quality. Body Mass Index (BMI) can be an indicator of health, so it can guide a person to control the food consumed. This study innovates the development of a manual BMI measurement tool at STMIK STIKOM Indonesia into a BMI measurement tool that can be accessed online with a concept called IoT (Internet Of Things). The design of the IoT Based BMI Measurement Tool at STMIK STIKOM Indonesia is expected to help lecturers, staff, and students at STMIK STIKOM Indonesia to be able to check their BMI regularly so that they can optimize the satwika lifestyle. The data of this research were obtained by conducting observation, e-questionnaire, and interview methods and then elaborated with qualitative descriptive to describe that the BMI measuring instrument can function and assist the academic community of STMIK STIKOM Indonesia in maintaining a satwika lifestyle.
\end{abstract}

Keywords: Satwika Life Style, BMI, Technology 


\section{INTRODUCTION}

Satwika lifestyle is a lifestyle that is recommended in the Hindu concept. Satwika comes from the word sattwam which means wise life style (Budiyasa, 2016). The satwika lifestyle refers to the understanding that the physical body should be maintained through wise thoughts and behavior in determining what is good and bad for the body so that it is always in a fit and fit state. To keep the body in optimal health condition, it is recommended to do sports and maintain a healthy diet.

The development of technology affects the lifestyle of modern society (Rahayu, 2020). The practical lifestyle triggers the growth of the food industry to continue to innovate. At present, the food industry from small to large scale has begun to turn to the internet for marketing and selling its products. Quoted from the Ministry of Health website (Widyawati, 2021), showing that through various digital platforms a lot of food is sold, regardless of type, and it cannot be filtered again, so it is impossible to know whether it is clean, healthy and has good nutritional content. The ease of access to food with the help of digital technology has not been matched by awareness of the importance of choosing foods that can have an impact on health levels. People's lifestyles like that can cause non-communicable diseases due to lack of attention to the nutritional needs of the body.

The problem of undernutrition and overnutrition in adolescents will increase susceptibility to disease, especially the risk of non-communicable diseases in the elderly such as heart disease, diabetes mellitus and stroke. If it continues into adulthood and gets married, it will be at risk to the health of the fetus it contains. NonCommunicable Diseases can be detected early by checking blood pressure, blood sugar, and BMI or abdominal circumference regularly. BMI calculation is a simple and easy way to detect noncommunicable diseases early. Body Mass Index is a simple index of weight to height used to classify overweight and obesity in adults. BMI is defined as a person's weight in kilograms divided by the square of height in meters $(\mathrm{kg} / \mathrm{m})$. BMI calculations are generally still done manually, so we need a system that can automatically measure body mass index and can be accessed online using a mobile phone or desktop. Research respondents consisted of lecturers, staff, and students of STMIK STIKOM Indonesia. Data from the survey using an equisionner, as many as $95.7 \%$ of 115 respondents agree that at work/campus respondents have tools and applications that can monitor Body Mass Index. Based on the survey results, a technological innovation is needed in measuring Body Mass Index that can be accessed online with a concept called IoT (Internet Of Things). The author has made observations on the Body Mass Index measuring device in STMIK STIKOM Indonesia and has determined several developments that can be carried out on the system including the addition of the ESP8266 module as a medium for sending data from Body Mass Index measurement results to the database and the data can be accessed via website.

This study uses a reference development conducted by several previous researchers. Research with the title "Perancangan Alat Ukur Indeks Massa Tubuh (IMT) Digital Berbasis Mikrokontroler" (Fadil dan Thamrin, 2020) designed a BMI device using the reverse engineering method, which is a method of developing a certain product that is used as a reference material to produce a new product with the development of certain components.

The next research reference is the study of a desktop-based nutrition monitor body mass index measurement system (Ekayana dkk., 2020). The method of electronic measurement of body mass system and height is divided into several stages, namely the initial stage to the final stage. The system consists of electronic hardware, mechanical hardware and software. Where electronic hardware 
consists of measuring body mass, measuring body length, signal processing module, LCD screen, serial communication and PC Laptop devices. For mechanical hardware, it consists of materials for measuring body length and body mass. The software consists of software on the signal processing module and software on the Laptop PC.

Research with the title "Rancang Bangun Alat Ukur Indeks Massa Tubuh menggunakan Sensor Ultrasonik, Load Cell, Mikrokontroller Arduino dan Koneksi dengan Smartphone" (Dwiyanto, 2019) be the third reference. The design of smartphone-based obesity measuring devices for the development of biomedical instruments on obesity measuring devices and then analyzing Load Cell and ultrasonic sensors. To make this measuring device, you need an ultrasonic HC-SR04 as a distance sensor, a 200kg Load Cell as a weight sensor, and Arduino Uno as a microcontroller.

Based on this data, a research was conducted with the title "Design of an IoT (Internet of Things)-Based Body Mass Index Measuring Tool at STMIK STIKOM Indonesia". The results of the research are expected to later be able to help lecturers, staff and students at STMIK STIKOM Indonesia to be able to check their BMI regularly so that they can optimize the Satwika lifestyle.

\section{METHOD}

The research method was carried out based on the research stages. The stages of the research carried out are as follows.

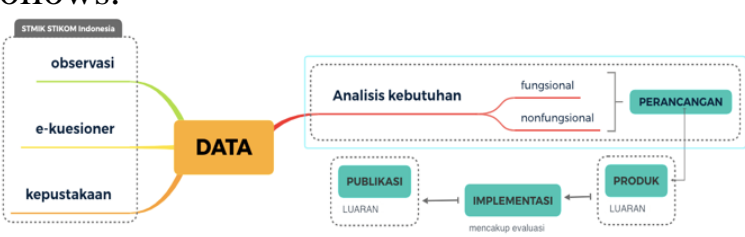

Figure 2.1 Research Stages

\subsubsection{Method of Collecting Data}

The data in this study were obtained by conducting observations, equestionnaires and literature studies. Methods of collecting data using a questionnaire is done by making nine questions whose respondents consist of lecturers, staff and students of STMIK STIKOM Indonesia. The author uses google form as a medium for making questionnaires. A total of 115 respondents consisting of lecturers, staff and students of STMIK STIKOM Indonesia have responded to the questionnaire made by the author.

The data obtained are used for analysis of functional and non-functional requirements. Functional requirements analysis is an analysis carried out to analyze the needs of the system itself.

Analysis of non-functional requirements is an analysis that is carried out based on the system but outside of the function of the system itself. Analysis of non-functional requirements is more about analysis carried out on the needs of the hardware used, software requirements and also analysis of brainware needs. After the needs analysis is complete, then proceed to the design stage of the IoT-based BMI measuring device.

\subsubsection{Design of Tools}

Tool design which includes software design and system mechanical design. Database design of the IoT-based body mass index measuring system. The database design design is named "SIMONTI". The use of the IoT-based Body Mass Index (BMI) Measuring Tool can be accessed through http://simontistiki.000webhostapp.com/logi n.php. 


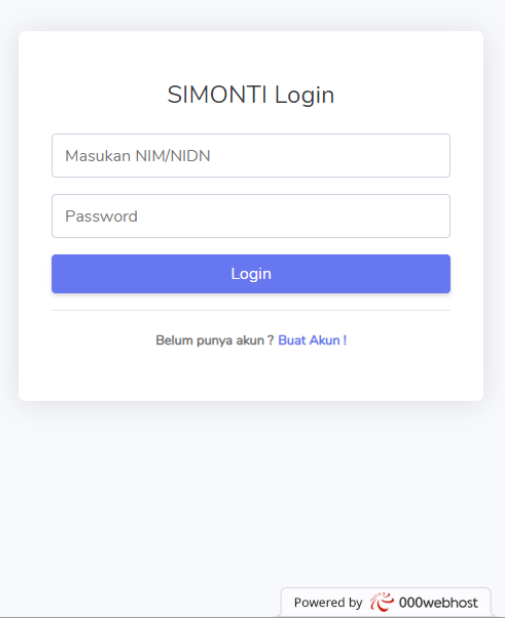

Figure 2.2 Login Interface

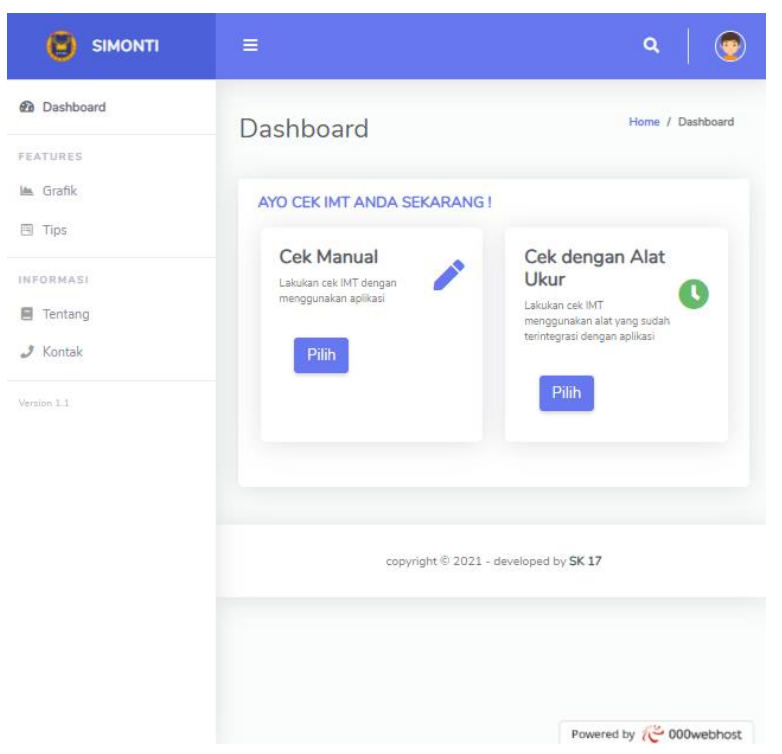

Figure 2.3 Dasboard Interface

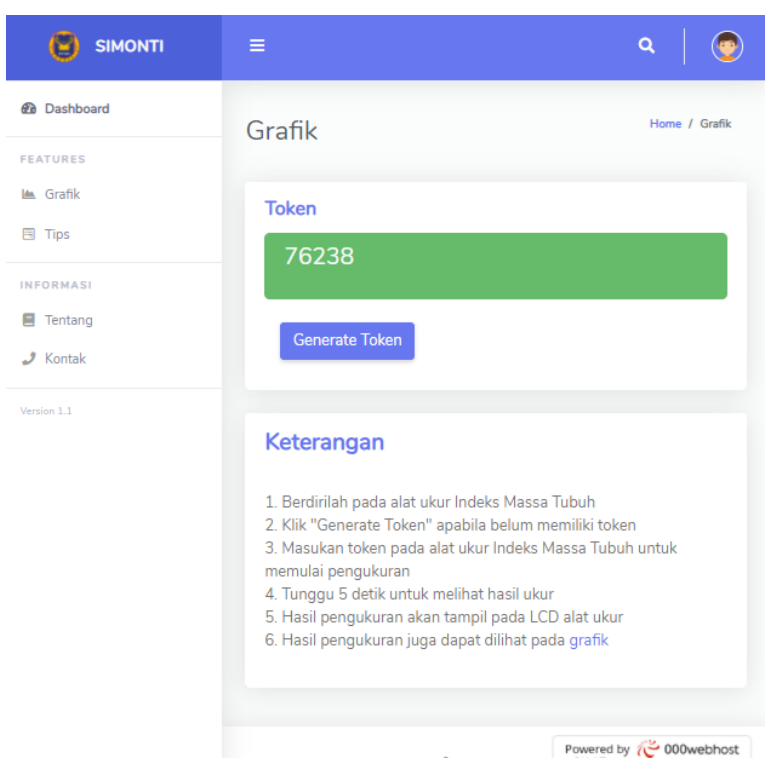

Figure 2.4 Generate Token

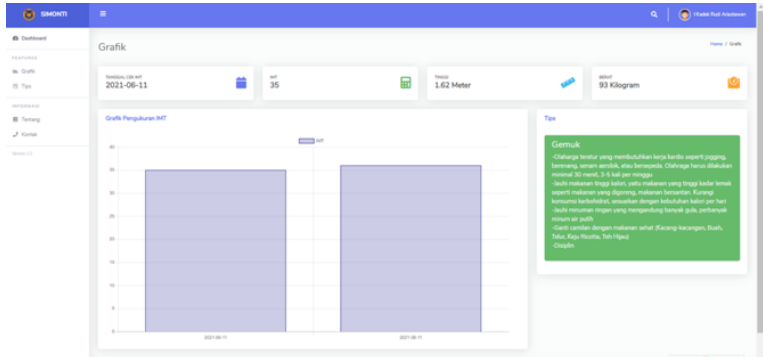

Figure 2.5 Grafic Interface

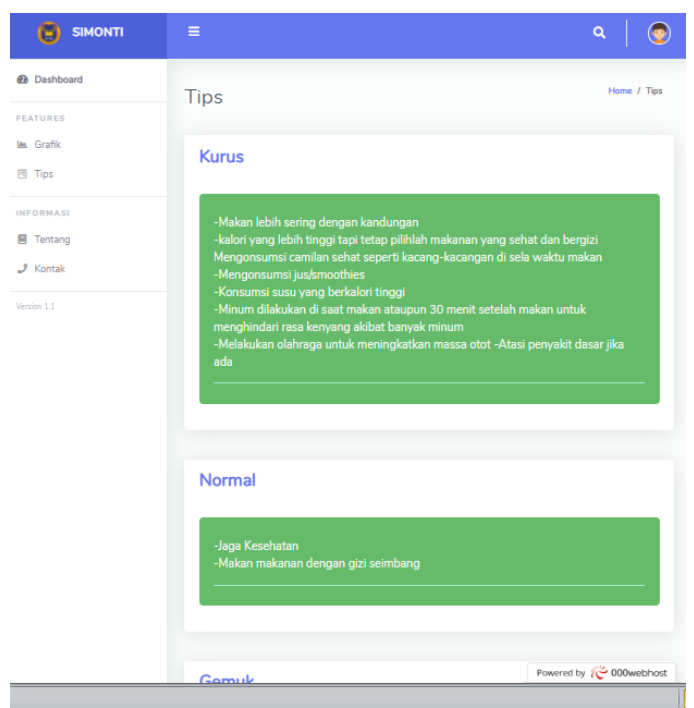

Figure 2.6 Tips Page

The mechanical design of the system has dimensions of $50 \mathrm{~cm}$ long, $50 \mathrm{~cm}$ wide, and $200 \mathrm{~cm}$ high.

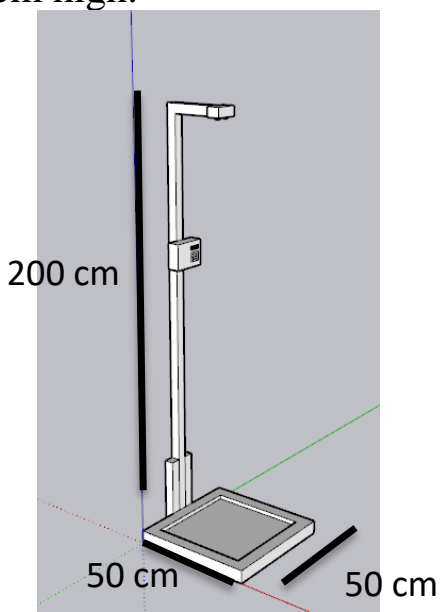

Figure 2.7. Mechanic System 


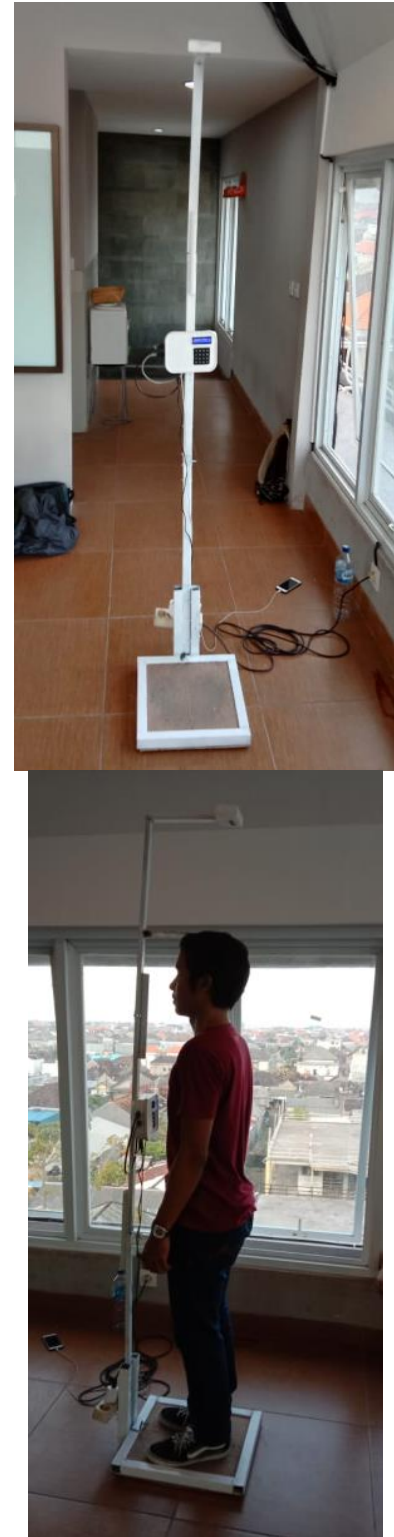

Figure 2.8. Mechanic System

The use of the application can be done in 2 ways, namely offline and online. As for how to use offline and online are as follows.

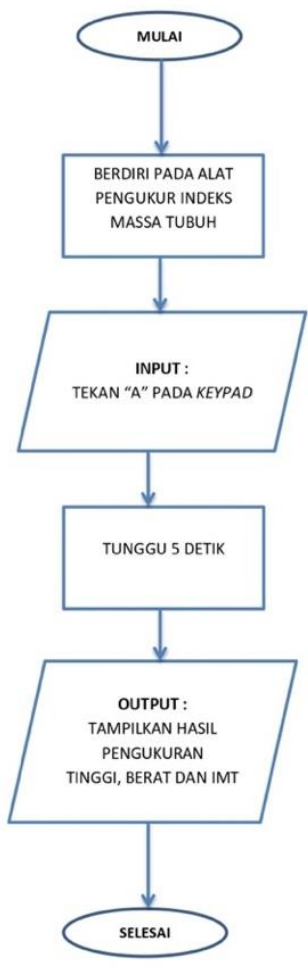

Figure 2.9. Offline use

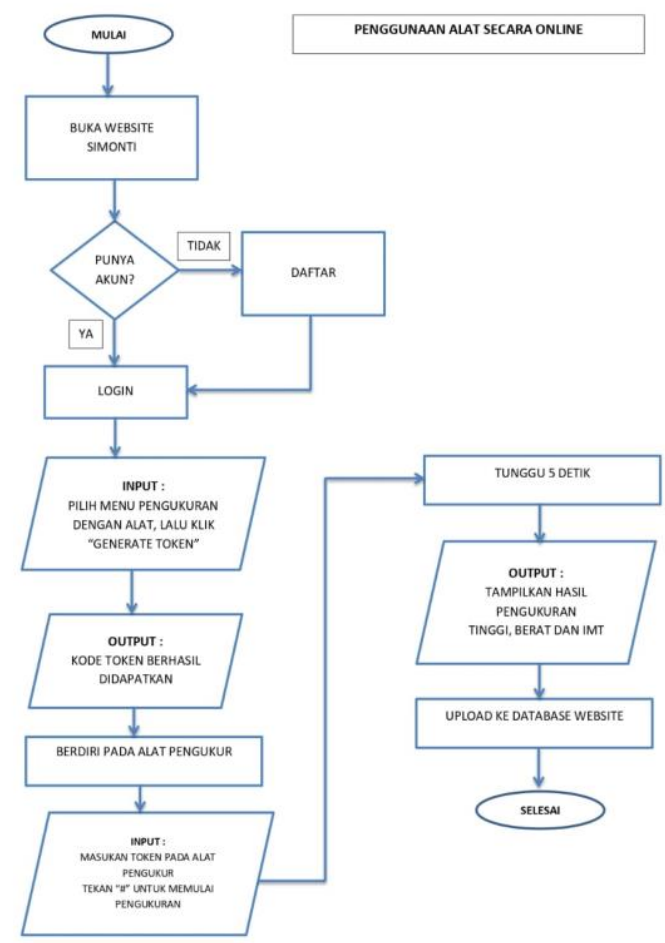

Figure 2.10. Online use 


\section{RESULTS AND DISCUSSION}

Taken 10 types of samples selected randomly at the testing stage. To ensure

that the system that is built is in accordance with the needs, then a test is carried out on the system against sampling using the percentage formula.

Measurement Percentage Testing success using the formula which is:

\begin{tabular}{|c|}
\hline Persentage $=($ Sensor Value/ \\
Raw Tool Value $) \times 100 \%$ \\
\hline
\end{tabular}

For the percentage of error testing used the formula:

\section{Persentage $=($ Raw Tool \\ Value-Sensor Value / Raw Tool Value) x $100 \%$}

Tests were carried out on 3 aspect categories, that is height measurement, weight measurement, and tool response time. The results are as follows.

\begin{tabular}{|c|c|c|c|c|}
\hline \multirow{2}{*}{ No } & Alat Baku & $\begin{array}{c}\text { Sensor } \\
\text { Ultrasonik }\end{array}$ & $\begin{array}{c}\text { Presentase } \\
\text { Sukses }\end{array}$ & $\begin{array}{c}\text { Presentase } \\
\text { Gagal }\end{array}$ \\
\cline { 2 - 5 } & $\mathrm{Cm}$ & $\mathrm{Cm}$ & $\%$ & $\%$ \\
\hline 1 & 175 & 173 & 98.85 & $1,15 \%$ \\
\hline 2 & 178 & 178 & 100 & 100 \\
\hline 3 & 165 & 162 & 98,18 & 1,82 \\
\hline 4 & 178 & 176 & 98,87 & 1,12 \\
\hline 5 & 169 & 166 & 98,22 & 1,78 \\
\hline 6 & 169 & 167 & 98,81 & 1,19 \\
\hline 7 & 178 & 177 & 99,43 & 0,57 \\
\hline 8 & 175 & 172 & 98,28 & 1,72 \\
\hline 9 & 170 & 169 & 99,41 & 0.59 \\
\hline 10 & 175 & 173 & 98,85 & 1,15 \\
\hline \multicolumn{7}{|c}{ Rata-rata } & 98,89 & 1,11 \\
\hline
\end{tabular}

Table 3.1 Height test

\begin{tabular}{|c|c|c|c|c|}
\hline No & Alat Baku & $\begin{array}{c}\text { Sensor Load } \\
\text { Cell }\end{array}$ & $\begin{array}{c}\text { Presentase } \\
\text { Sukses }\end{array}$ & $\begin{array}{c}\text { Presentase } \\
\text { Error }\end{array}$ \\
\cline { 2 - 5 } & $\mathrm{Kg}$ & $\mathrm{Kg}$ & $\%$ & $\%$ \\
\hline 1 & 80 & 81 & 98,76 & 1,24 \\
\hline 2 & 70 & 69 & 98,57 & 1,43 \\
\hline 3 & 95 & 93 & 97,89 & 2,11 \\
\hline 4 & 87 & 86 & 98,85 & 1,15 \\
\hline 5 & 58 & 56 & 96,55 & 3,45 \\
\hline 6 & 50 & 46 & 92 & 8 \\
\hline 7 & 87 & 86 & 98,85 & 1,15 \\
\hline 8 & 60 & 57 & 95 & 5 \\
\hline 9 & 72 & 70 & 97,22 & 2,78 \\
\hline 10 & 51 & 50 & 98,03 & 1,97 \\
\hline & \multicolumn{2}{|c|}{ Rata-rata } & 97,172 & 2,828 \\
\hline
\end{tabular}

Table 3.2 Weight test

\begin{tabular}{|l|c|}
\hline \multicolumn{1}{|c|}{ Testing } & Response Time \\
\hline First & 10 \\
\hline Second & 11 \\
\hline Third & 10 \\
\hline Fourth & 10 \\
\hline Fifth Average & 11 \\
\hline \multicolumn{2}{|c|}{ Ave } \\
\hline
\end{tabular}

\section{Table 3.3 Duration Accessable}

Overall system testing aims to determine the results of system performance after each component has been integrated with each other. Overall system performance can be seen through the following table.

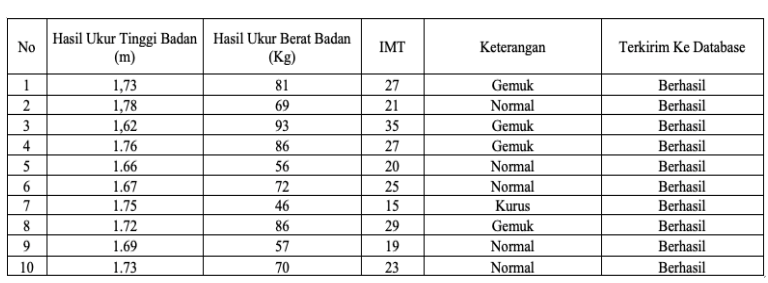

Table 3.4 Testing Result

Of the ten comparison tests performed on the ultrasonic sensor and meter, the average error is $0.4 \%$. On loadcell sensors and analog scales there is an average error of $0.7 \%$. Furthermore, the test of sending measurement data to the database using the ESP-8266 nodeMCU when the overall measurement is complete with a $100 \%$ success rate and an average delivery duration of 15.4 seconds.

\section{CONCLUSION}

The success of the IoT (Internet Of Things)-based Body Mass Index test at STMIK STIKOM can function properly and can be used by the STIKI Academic Community who cares about health to control and guide appropriate lifestyle choices based on the Satwika lifestyle. The development of the tool is expected to continue considering that the tool is still a simple prototype. In addition, it is expected to be a reference for other research in the future. 


\section{REFERENCE}

Budiyasa, G. 2016. "MAKANAN

SATWIKA DAN PROFIL LIPID

PADA BHAKTA SAI DENPASAR".

Dharmasmrti: Jurnal Ilmu Agama

dan Kebudayaan, 15(28), 57-66.

https://doi.org/10.32795/ds.v15i28.6.

Dwiyanto, M. 2019. RANCANG

BANGUN ALAT UKUR INDEKS

MASSA TUBUH

MENGGUNAKAN SENSOR

ULTRASONIK, LOAD CELL,

MIKROKONTROLLER

ARDUINO DAN KONEKSI

DENGAN SMARTPHONE.

Jurusan Teknik Elektro Unjani.

Ekayana, A. A. G., Hartawan, I. N. B., dkk. 2020. "Body mass index

measurement system as a desktopbased nutrition monitor". Journal of Physics: Conference Series,

1469(1).

https://doi.org/10.1088/1742-

6596/1469/1/012104.

Fadil, M., dan Thamrin, T. 2020.

"Perancangan Alat Ukur Indeks

Massa Tubuh (IMT) Digital Berbasis

Mikrokontroler". VoteTEKNIKA:

Jurnal Vocational Teknik ..., $8(1)$.

Rahayu, P. N. 2020. "Pengaruh Gaya

Hidup Serba Instan dan Praktis

Terhadap Perilaku Konsumen Dalam

Dunia Digital".

Widyawati 2021. "Gizi Tak Seimbang Saat

Remaja Berisiko Tingkatkan Penyakit

Tidak Menular". 